\title{
Pre-Service Biology Teacher Preparation in the Usa And Ukraine: Comparative Study of Professional Education Training
}

\author{
N. M. Shchur* \\ Department of Chemistry and Biology, Ternopil Volodymyr Hnatiuk National Pedagogical University, Ternopil, Ukraine \\ *Corresponding author: natalya.schur@ukr.net
}

Received April 08, 2014; Revised April 21, 2014; Accepted April 28, 2014

\begin{abstract}
Developing the teacher education has become popular tendency all over the world. It is caused by the fact that teacher training influence both educator effectiveness and students' outcomes. Teacher education is treated as a lifelong learning that goes from the pre-service training to the retirement. Increasing the level of pre-service teacher education is vital for improving teacher quality and students' achievements insofar as it develops the basic teacher competences which are necessary to accomplish teacher work correctly. In Ukraine there are a lot of challenges in pre-service teacher education that have to be dealt with. The experience of developed countries is very essential for identifying the most appropriate ways to cope with the challenges in Ukrainian systems of teacher training. In this article there have been investigated the peculiarities of pre-service biology teacher education in the USA and Ukraine. The advantages and disadvantages of Ukrainian professional education training of pre-service biology teachers and the strategies for its improvement have been determined on the basis of comparative analysis of both countries.
\end{abstract}

Keywords: pre-service biology teacher education, professional education training

Cite This Article: N. M. Shchur, "Pre-Service Biology Teacher Preparation in the Usa And Ukraine: Comparative Study of Professional Education Training.” American Journal of Educational Research, vol. 2, no. 5 (2014): 278-282. doi: 10.12691/education-2-5-7.

\section{Introduction}

Teaching is a complicated and demanding intellectual work. It cannot be performed correctly without the adequate training. Research evidences shows that the most effective way to enhance the quality of teaching and learning is to improve pre-service teacher education. Preservice teacher education is the first entry point into the teacher profession. It plays a key role in determining the teacher quality [6].

The content of pre-service biology teacher training includes the general education courses, the subject-matter courses, professional education courses and practical school experience. Researches show that pedagogical knowledge more influences the student achievements than subject matter knowledge [6]. Thus this study is devoted to the professional education training of pre-service biology teachers.

Ukraine faces many challenges of delivering high quality pre-service biology teacher education. The experience of pre-service biology teacher training in the developed countries, especially in the USA is of great importance for developing and modernizing Ukrainian system of teacher education.

\section{Methodology}

This study is a natural comparative analysis. Data used in this study are collected from primary and secondary sources. Primary data are collected through examining and comparative analysis of pre-service biology teacher training programs of Illinois State University, University of Connecticut, Shepherd University, University of North Carolina Wilmington, Harvard University, Ternopil Volodymyr Hnatiuk National Pedagogical University, Pavlo Tychyna Uman State Pedagogical University, Ivan Franko Lviv National University, Zaporizkui National University. Secondary data has been collected from various sources including scientific articles and researches of Ukrainian and American scholars, the official websites and papers of U. S. Department of Education, Ministry of Science and Education of Ukraine. The study will be a comparable study based on the collected data and information.

\section{Objectives of the Study}

The main objective of this study is to examine the strategy to improve the professional education training of 
pre-service biology teachers in Ukraine. To carry out this study the following objectives must be achieved.

1. To provide the comparative analysis of professional education training of pre-service biology teachers in the USA and Ukraine.

2. To determine the advantages and disadvantages of Ukrainian professional education training of pre-service biology teachers.

3. To identify the strategies to improve the professional education training of pre-service biology teachers in Ukraine.

\section{Peculiarities of the Pre-service Biology Teacher Education in the USA and Ukraine}

In the the USA pre-service biology teachers are educated at schools or colleges of education, which are the structural units of the university, and at liberal arts colleges or teacher colleges, which are independent structural units. At these educational institutions studies normally last for four years (eight semesters) and students must earn a minimum of 120 credits.

Having successfully completed training at the educational institutions mentioned above, future teachers receive a diploma of Bachelor of Arts / Science in Biology (Teacher Education Major). After receiving a Bachelor's degree, future biology teachers can continue their studies and apply for the Master's programs. These programs last for one or two years.

In Ukraine biology teacher training is provided by the pedagogical universities, academies and classical universities. In order to get the diploma of Bachelor students should study at university or academy for four years. To receive the diploma of Master pre-service biology teachers should study one or two years more. It is possible to receive the diploma of integrated Master without getting a bachelor's degree. Such program lasts for five years [2].

One of the main differences between Ukrainian and American systems of teacher education is that the majority of American students begin to work as a teacher after four years studying and receiving a Bachelor's degree. In Ukraine almost all students study at university or academy for five years and begin their teacher career after getting Master's or Specialist's diploma.

Having analyzed pre-service biology teacher training programs in the USA, one can draw the conclusion that American universities offer three types of training: undergraduate successive training programs, undergraduate integrated training programs, graduate programs.

According to the first type of programs, all students take general education and content area courses during the first years of study. Over the next two or three years those students who intend to become biology teachers enter the university college or school of education where they begin to study professional education courses. Those students who have already completed Bachelor's degree also can enter the university college or school of education.

According to the second type of programs, applicants who wish to become biology teachers enter the four-year university college or school of education and begin to study general education, content area and professional education courses concurrently.

The third type of programs proposed one- or two-year graduate teachers studies. These programs are designed for:

1. Pre-service biology teachers who took the professional education courses for two or four years of university studies and wish to develop their professional competences;

2. Pre-service biology teachers who completed nonteaching degree but are going to become an educator;

3. Practicing biology teachers who are licensed through the alternative pathway;

4. Practicing teachers who wish to improve their professional competences or get the qualification "leader of education”.

The four-year teacher colleges which are not the structural units of universities offer integrated teacher training programs and the liberal arts colleges offer successive teacher training programs. After successful completion of these programs students obtain a Bachelor's degree.

In Ukraine there are also successive teacher training programs and integrated teacher training programs. Pedagogical universities and academies offer integrated teacher training programs. These programs provide the optimum combination of content area and professional education studies.

Successive teacher training programs are offered by the classical universities. For instance, at Zaporizkui National University the professional education courses begin from the 6th semesters. There is only one professional education course requirement "Biology Teaching Methods". During the 9th semester students who are studying for their Specialist Diploma continue to take professional education course such as "Modern Biology and Chemistry Teaching Techniques and Methods". Students who are working for their Master Diploma take the following courses: "Higher Education and the Bologna process", "Biology Teaching Methods in Higher School”, "Pedagogy and Psychology in Higher school". The peculiarities of the educator preparation at classical universities in Ukraine is "focus on faculty training, especially in the natural science, pure science and humanities" [[5], p. 175]. However, many classical university graduates work as school teachers.

In Ukraine successive teacher training programs are criticized by many scholars. The main disadvantage of these programs is insufficient level of teaching practice and pedagogical direction of studies. Analyzing the teacher training in Ukraine V. Savchuk states: "The mass reorganization of pedagogical universities into the classical universities in recent years negatively affected the quality of teacher training so long as in some new classical universities the number of professional education courses has been unreasonably reduced. In addition, such subjects as "Fundamentals of Teacher Proficiency", "Introduction to Teaching”, "Teaching Secondary School Subjects with Using Computer Technology", "Methods of Educational Work" are not studied at classical universities. There have been removed propaedeutic teaching practice in the children health-improving camps and significantly reduced teaching practice in the secondary schools” [[8], p. 
20]. Scholar notes that as a result of this policy novice teachers often do not have any idea about teaching methods and national education issues [[8], p. 20].

I. Ziaziun supports above mentioned idea. On his opinion, trend to reorganize the pedagogical universities into the classical universities negatively influences the teacher training insofar as the specificity of the pedagogical university and classical university activities is somewhat different. Thus they cannot replace each other [[9], p. 106].

Having analyzed American biology teacher training programs, one can come to the conclusion that in the USA there are not such problems. For instance, at Illinois State University which offers successive teacher training programs students must take 10 professional education courses and undertake teaching practice (36 credits) that is 29 percent of total credits number required for obtaining Bachelor's degree. In Shepherd University which provides integrated teacher training programs it is obligatory for pre-service biology teachers to take 9 professional education courses and undertake teaching practice (35 credits) that is 29,2 percent of total credits number required for obtaining Bachelor's degree. From these data one can conclude that in USA there is no difference between successive and integrated teacher training programs in the number of professional education courses.

In Ukraine, like in the USA, there are also graduate biology teachers training programs. However, the main difference between American and Ukrainian graduate programs lies in the fact that in Ukraine it is possible to obtain a Master's degree of education only after receiving a Bachelor's degree in teaching. That is, in Ukraine there is no analogue of one or two-year Master's or post baccalaureate programs that allow professionals from noneducational fields become a teacher. In addition, Ukraine has no analogue of alternative teacher certification programs which "provide a pathway for people to enter the teaching profession without following the conventional undergraduate 4-year path”[[4], p. 3]. These programs have been developed because of teacher shortage. Their purpose is to increase the supply of educators.

Many American scientists criticize these certification programs. The opponents of alternative teacher certification consider that individuals licensed through the alternative routes to teacher certification have poor teacher professional knowledge and skills. But on the other hand, scholars supporting this type of certification claim that persons who have not completed a traditional teacher training programs have more quality content area knowledge than those who have attended such programs [4].

As mentioned early, in Ukraine there is a problem of biology teacher training at classical universities. This problem is similar to the problem of the alternative teacher certification in the USA In fact, the graduates of Ukrainian classical universities, like American teachers licensed through the alternative certification rout, have more substantial subject matter knowledge compared with the graduates of pedagogical universities or academies but are not sufficiently prepared to perform teaching work correctly.

\subsection{Professional Education Training in the USA and Ukraine: Theoretical Component}

In the USA the same as in Ukraine the requirements of biology teacher training programs are general education courses, content area courses, professional education courses and teaching practice. For our investigation it is important to analyze the peculiarities of professional education courses and teaching practice in both countries.

It is important to mention that in the USA each university can set its own professional education requirements for pre-service biology teacher. For instance, at Illinois State University the secondary education requirements for pre-service biology teachers are "Foundation of Psychology", "Educational Psychology", "Issues in Secondary Education", "Social Foundations of Education/Introduction to Philosophy of Education", "Instruction and Evaluation Methods", "Literacy in Content Areas", “Student Teaching”. Biology education course requirements are "Introduction to Teaching Science" (Seminar), "Methods of Teaching Biology", "Methods of Teaching Biology" (Laboratory), "Student Teaching Seminar”.

In Ukraine as well as in the USA the professional education requirements depend on the university. For instance, in Pavlo Tychyna Uman State Pedagogical University general pedagogy requirements for pre-service biology teachers are "Introduction to Teacher Profession", "Pedagogy", "Psychology”, "Foundations of Pedagogical Creativity", "Physiology of Aging and School Hygienics"; elective courses - "Foundations of Pedagogical Measuring”, "Extracurricular Activities in Chemistry". Content-specific pedagogy requirements are "Methods of Biology and Natural Science Teaching", "Methods of Upbringing", "Methods of Chemistry Teaching", "Methods of Organizing Student Naturalistic Activities"; elective courses - "Methods of Organizing Student Extracurricular Activities", "Methods of teaching the course "Foundations of Health".

The comparative analysis of pre-service teacher training programs in the USA and Ukraine shows that American programs do not include such course as "Pedagogy" which covers the study of two topics: "Theory of Learning (Didactics)" and "Theory of Upbringing”. In Ukraine this course is a prerequisite and basis for studying the other general and content-specific pedagogy courses. Moreover, American pre-service biology teacher programs against Ukrainian pre-service biology teacher programs are not focused on such issues as the structure of instruction process, principles and regularities of learning.

The other difference between American and Ukrainian biology teacher training programs lies in the fact that in the USA the professional education courses do not include such issues as theory and methods of student upbringing, nature and functions of upbringing process at school, its regularities and principles, methods of organizing student extracurricular activities. In the USA pre-service biology teachers do not learn about organizing children collective and its impact on student personality.

Therefore, the peculiarity of Ukrainian biology teacher education is the statement that the task of secondary education is not only to teach but also to bring up. Accordingly, Ukrainian scientists treat upbringing as a complicated process of forming personality, creating 
optimum conditions for his or her physical, psychological and social development. The main objective of upbringing is the comprehensive harmonious development of student personality which embraces forming some characteristics and dispositions in accordance with the requirements of ethical, intellectual, working, physical and aesthetic upbringing.

\subsection{Professional Education Training in the USA and Ukraine: Practical Component}

In the USA pre-service biology teachers undertake teaching practice during the last semester of college or university study [3]. In Ukraine students undertake teaching practice during the last semester of the $4^{\text {th }}$ and the $5^{\text {th }}$ years of study. In the USA as well as in Ukraine teaching practice begins with the initial conference. During this meeting the university supervisor, cooperating teacher and teacher candidate discuss the student teacher program. In both countries teacher candidate must give the lessons in Biology under the direction of cooperating teacher. This cooperating teacher, along with the university supervisor, must guide and evaluate the student teacher work. All lessons' plans prepared by the student teacher should be agreed with the cooperating teacher in advanced. The student teacher has also to participate in school and community activities. To enrich teaching experience it is suggested for pre-service biology teacher to visit lesson of other teacher or student teachers.

The university supervisor visits the student teacher a minimum of one time per two weeks. These visits must allow for a formal observation, written feedback and individual conferences with the student teacher and the cooperating teacher.

In the USA, like in Ukraine, there is held the final conference at the end of teaching practice. During this meeting the university supervisor, cooperating teacher and teacher candidate discuss and assess the work of teacher candidate [3].

In both countries the total number of weeks of student teaching varies from university to university. In the USA the teaching practice lasts for $12-16$ weeks. In Ukraine student teaching continues for 16 weeks at pedagogical universities or academies and 8 weeks at classical universities.

One of the peculiarities of modernizing pre-service teacher education in Ukraine is enhancing practical biology teacher training. $M$. Nagach claims that one of the problems of practical pre-service teacher training in Ukraine is lack of coordination between theoretical and practical components of professional education training. This causes the other problem such as students' inability to put the theoretical knowledge into practice and unreadiness for teacher performance. In addition, there is no effective collaboration between the secondary schools and universities in organizing and realizing practical preservice teacher training [7].

Mentioned above statement is supported by American scientists. On their opinion, the most essential obstacle of qualitative pre-service teacher training is taking the most of teacher undergraduate courses in the academic departments. Thus teachers lack practical relevance [1].

Having analyzed American system of pre-service teacher education, one can draw the conclusion that in the
USA there are the ways of solving this problem. One of these ways is clinical experiences. It is a pre-student teaching field experience which includes observation, simulation lab exercises, professional meeting, noninstruction assisting, microteaching and others. The clinical experiences take place in off-campus clinical teaching centers, in local schools, in professional development schools, in campus laboratory schools, etc.

It is possible to increase the total credits number required for practical teacher training by means of clinical experiences. For example, at Illinois State University the total number credits for practical teacher training increase from 33 percent to 44 percent. In University of Connecticut (UCONN) the total number credits for practical teacher training increase to 56 percent.

The other positive side of undertaking teaching practice is student teaching at professional development school. It is an innovative educational institution that has been established as a result of a partnership between schools or colleges of education and public schools. One of the professional development school tasks is improving preservice teacher training through extensive clinical experience and student teaching. At professional development schools the studies continue for 32 weeks during the last year of study [[7], p. 11].

\section{Conclusions and Recommendations}

Comparative analysis of pre-service teacher education in the USA and in Ukraine made it possible to determine the advantages and disadvantages of Ukrainian professional education training of pre-service biology teachers and to identify the strategies to improve it.

The first advantage lies in the fact that in Ukraine there is no analogue of graduated programs and alternative teacher certification programs which provide the opportunity for professionals from non-educational fields to become a teacher.

The second advantage is theoretical component of professional education training of pre-service biology teachers which is more fundamental and academic oriented than in the USA.

The third advantage is focus of Ukrainian professional education training programs on upbringing process at school. This provides the educators with the adequate knowledge and skills to accomplish the comprehensive harmonious development of pupils’ personality.

The disadvantage of Ukrainian professional education training of pre-service biology teachers is its practical components. Firstly, it is a students' inability to turn theoretical knowledge into practice and their unreadiness for teacher performance. One of the most effective ways which could be used to copy with this problem is clinical experience. The most appropriate clinical experience activity for this aim is microteaching insofar as it provides students with the opportunity to put the knowledge gained at university into practice and acquire teacher performance experience before undertaking teaching practice. As a result, teaching practice is becoming more effective.

Secondly, it is insufficient level of professional education training of pre-service biology teachers at classical universities. To cope with this problem it might be implemented the experience of pre-service biology 
training at professional development schools. In addition, this experience could create the opportunity for effective collaboration between the secondary schools and pedagogical universities or academies.

\section{References}

[1] Feiman-Nemser, S., Teacher preparation: Structural and Conceptual Alternatives [Online] Aviable: http://ncrtl.msu.edu/http/ipapers/html/pdf/ip895.pdf

[2] Field Conception of Developing Lifelong Teacher Education [Online] Aviable: http://osvita.ua/legislation/Ser_osv/36816/

[3] Handbook for Student Teaching. The Cecilia J. Lauby Teacher Education Center. Illinois State University [Online] Aviable: http://education.illinoisstate.edu/downloads/teacher_education/han dbookstt.pdf

[4] Heine, H., Teacher Certification Systems. Policy Brief. Pacific Resources for Education and Learning, 2006, 1-22.
[5] Klintsova, M. M., "Peculiarities of Teacher Training at Classical University". The problems of modern teacher education, 8, Yalta, 174-179, 2005.

[6] Musset, P., Initial Teacher Education and Continuing Training Policies in a Comparative Perspective: Current Practices in OECD countries and a literature review on potential effects OECD Education Working Papers, 2010, 50 p.

[7] Nagach, M. V., Future Teachers' Preparation in the Professional Development Schools of the USA. The thesis on competing a scientific degree of a Candidate of Pedagogical Science by the specialty 13.00.04 - "Theory and Methodology of Professional Education”. The Education Management University of the Academy of Pedagogical Sciences of Ukraine, Kyiv, 2008, 21 p.

[8] Savchuk, V., "Perspectives of the In-service Teacher Education of Ukraine with respect of European integration: Philosophy Aspect”, Modern Pedagogical View, 1, 20-22, 2010.

[9] Ziaziun, I. A., "The Process of Modernizing Modern Teacher Education in Ukraine”, Professional Training: Pedagogy and Psychology: Polish and Ukrainian Journal, VIII, Kyiv, 105-115, 2006. 